\title{
Direct Analysis of Dark Honeys for Total Content of Copper and Its Fractionation Forms
}

\author{
Pawel Pohl • Iwona Sergiel
}

Received: 15 November 2010 / Accepted: 10 February 2011 /Published online: 1 March 2011

(C) The Author(s) 2011. This article is published with open access at Springerlink.com

\begin{abstract}
Suitability of direct analysis of honey solutions by air-acetylene flame atomic absorption spectrometry for reliable measuring total concentrations of $\mathrm{Cu}$ was evaluated and compared with determinations completed after open vessel wet oxidative digestion of honeys with a mixture of $\mathrm{HNO}_{3}$ and $\mathrm{H}_{2} \mathrm{O}_{2}$. Total $\mathrm{Cu}$ concentrations determined in amber to dark color raw honeys were within $0.95-1.68 \mathrm{mg} \mathrm{kg}^{-1}$. Additionally, solutions of honeys were subjected to fractionation analysis by means of a two-column solid phase extraction procedure with a non-ionic adsorbing resin Amberlite XAD-16 and a strongly acidic cation exchanger Dowex $50 \mathrm{~W} \times 8-200$. Another set of solutions was subjected to fractionation analysis using ultrafiltration with membranes of molecular weight cut-off size of 100, 50, 30, 10, and $5 \mathrm{kDa}$. Both approaches used to partition $\mathrm{Cu}$ species enabled to obtain information on chemical and physical fractionation patterns. It seems that predominant classes of species (67-94\%) are cationic and residual species which could be the most accessible forms of $\mathrm{Cu}$ from honey due to very low molecular size and possible association with certain organic compounds.
\end{abstract}

P. Pohl $(\bowtie)$

Department of Analytical Chemistry, Faculty of Chemistry,

Wroclaw University of Technology,

Wybrzeze Stanislawa Wyspianskiego 27,

50-370 Wroclaw, Poland

e-mail: pawel.pohl@pwr.wroc.pl

I. Sergiel

Department of Biotechnology, Faculty of Biological Sciences,

University of Zielona Gora,

Prof. Z. Szafrana 1,

65-516 Zielona Gora, Poland
Keywords $\mathrm{Cu} \cdot$ Honey Direct analysis $\cdot$ Solid phase extraction · Ultrafiltration · Flame atomic absorption spectrometry

\section{Introduction}

Raw honeys demonstrate a great variability in the content for $\mathrm{Cu}$ that is dependent on botanical and geographical origins of floral resources available for bees and different kind of impurities that bees carry from surroundings into a hive (Pohl 2009). Another source of contamination could be beekeepers themselves and their equipment and tools used for honey processing. High concentrations of $\mathrm{Cu}$ in honey, even up to $35 \mathrm{mg} \mathrm{kg}{ }^{-1}$, can indeed indicate contaminations related to honey processing, shipping, and storage (Baroni et al. 2009; Pohl 2009). This is because honey is acidic and may release $\mathrm{Cu}$ and other related elements $(\mathrm{Cr}, \mathrm{Fe}, \mathrm{Ni})$ by contacting with surfaces of steel and galvanized tools and containers during harvesting, producing, and packing (Paramas et al. 2000).

As in case of other foodstuffs, bio-accessibility of $\mathrm{Cu}$ from honey depends on different factors, including physicochemical forms of $\mathrm{Cu}$ species and other dietary components present (Gaetke and Chow 2003). Up to 50\% of a total $\mathrm{Cu}$ intake can be absorbed in a gastrointestinal digestion tract, mostly as simple $\mathrm{Cu}$ (II) ions and species of $\mathrm{Cu}$ bound to amino acids (histidine, methionine, cysteine) and organic acids (citric, gluconic, lactic, acetic; Turnlund et al. 1997; Wapnir 1998). Possible toxicity of high concentrations of $\mathrm{Cu}$ can be manifested in neurodegenerative disorders and propensity of simple $\mathrm{Cu}$ ions to participate in formation of reactive oxygen species (ROS; Bremner 1998). The latter species are capable of reacting 
with practically all biological molecules, including lipids, proteins, and DNA, causing their oxidative damage (Gaetke and Chow 2003). An ability of polyphenols to chelate $\mathrm{Cu}$ ions can however result in antioxidative effects, i.e., lowering $\mathrm{Cu}$ redox activity, inhibiting ROS formation, or scavenging these species (Andrade et al. 2005).

In reference to this, an ability to determine not only total concentrations of $\mathrm{Cu}$ in honey but also differentiate and quantify distinct $\mathrm{Cu}$ species or their classes differing due to certain physicochemical properties, including for example charge, reactivity, or molecular weight size, seems to be of special significance and importance. Information on $\mathrm{Cu}$ speciation would be more appropriate to predict possible physiological or nutritional effects of this element. This however implies special procedures and methods of analysis that enable separating and distinguishing various $\mathrm{Cu}$ species. Unfortunately, overwhelming literature reports devoted to honey analysis are merely focused on total concentrations of $\mathrm{Cu}$ and other elements.

This work was aimed at direct analysis of honey by means of flame atomic absorption spectrometry (F-AAS) for total concentrations of $\mathrm{Cu}$ in several amber to dark color honeys. For that reason, an appropriateness of a more effortless and faster method for determining total quantities of $\mathrm{Cu}$ in mentioned honeys was evaluated. In this alternative method of analysis, samples of honey were dissolved and diluted in water and directly analyzed by FAAS using external calibration with aqueous standard solutions. Although a two-column solid phase extraction (SPE) procedure using a non-ionic macroreticular adsorbing resin Amberlite XAD-16 coupled to a gel strong cation exchange resin Dowex 50W $\times$ 8-200 was already applied to partition $\mathrm{Cu}, \mathrm{Fe}$, and $\mathrm{Mn}$ species in blossom honeys (Pohl and Sergiel 2010), here both. SPE and ultrafiltration (UF) procedures were used to fractionation analysis of fractionate $\mathrm{Cu}$ species in more nutritionally relevant dark honeys. In this way, it was possible to discriminate distinct chemical and physical fractions of $\mathrm{Cu}$ species, respectively, and compare results achieved with both approaches in respect to special features of certain groups of compounds binding $\mathrm{Cu}$ ions. Accordingly, a chemical partitioning of $\mathrm{Cu}$ in analyzed honeys was carried out using a two-column SPE and resulted in distinguishing three operationally defined fractions differ due to hydropohobicity and charge of $\mathrm{Cu}$ species. Fractionation due to molecular weight of species with which $\mathrm{Cu}$ is associated was attained when honey solutions were ultrafiltrated through membranes with molecular weight cut-offs (MWCO) between 5 to $100 \mathrm{kDa}$. With this complementary data, it was possible to attribute a more defined chemical structure to separated fractions and predict $\mathrm{Cu}$ availability from honey.

\section{Materials and Methods}

\section{Instrumentation}

A Perkin Elmer 1100 B air-acetylene F-AAS was used to determine $\mathrm{Cu}$ concentrations. Operating conditions selected for F-AAS followed manufacturer recommendations given for $\mathrm{Cu}$ measurements in a lean flame, i.e., flow rates of fuel and oxidant of 1.2 and $8.01 \mathrm{~min}^{-1}$, respectively, an analytical absorption line wavelength of $324.8 \mathrm{~nm}$, a spectral bandwidth of $0.7 \mathrm{~nm}$, and a HCL lump current of $15 \mathrm{~mA}$. Absorbance readings were integrated at $0.1 \mathrm{~s}$ intervals over a 1 -s integration time. Three replicate measurements were made and averaged in each read cycle. Solutions were analyzed versus aqueous standard solutions of $\mathrm{Cu}$ at concentrations within a $0.05-1.00 \mathrm{mg} \mathrm{l}^{-1}$ range and suitable procedural reagent blanks. An instrumental detection limit of $0.006 \mathrm{mg} \mathrm{l}^{-1}$ was assessed for $\mathrm{Cu}$ under these operating conditions. Precision expressed as relative standard deviation (RSD) for three replicate measurements of $0.05,0.10$, and $0.20 \mathrm{mg} \mathrm{l}^{-1} \mathrm{Cu}$ solutions varied from 0.9 (at $0.20 \mathrm{mg} \mathrm{l}^{-1}$ ) to $5.5 \%$ (at $0.05 \mathrm{mg} \mathrm{l}^{-1}$ ).

\section{Reagents and Materials}

Analytical reagent grades of $\mathrm{HCl}, \mathrm{HNO}_{3}, \mathrm{NaOH}$, and $\mathrm{C}_{2} \mathrm{H}_{5} \mathrm{OH}$ were purchased from POCh (Gliwice, Poland). A 1,000-mg $1^{-1}$ standard solution of $\mathrm{Cu}$ from Merck KGaA (Darmstadt, Germany) was used to prepare standard solutions for external calibration. Ultra-pure water from a Pro-11G reverse osmosis water purification system (Wigo, Wroclaw, Poland) was used in all preparations. Glass columns from Sigma-Aldrich (Saint Louis, MO, USA) with coarse frits and Teflon stopcocks were used for SPE. Sigma-Aldrich non-ionic macroreticular adsorbing Amberlite XAD-16 (mesh size 20-60, surface area $800 \mathrm{~m}^{2} \mathrm{~g}^{-1}$, dipole moment $0.3 \mathrm{D}$ ) and a gel-type strongly acidic cation exchange Dowex 50W × 8-200 (mesh size 100-200, sorption capacity $1.7 \mathrm{meq} \mathrm{ml}^{-1}$ ) resins were used. A ColeParmer 4-channel MasterFlex L/S peristaltic pump (Vernon Hill, IL, USA) was used to maintain and control flows of solutions through columns.

\section{Sample Preparation}

Ripened amber to dark color honeys, including buckwheat (B), buckwheat-goldenrod (BG), heather $(\mathrm{H} 1, \mathrm{H} 2)$, and honeydew (HD1, HD2), were kept in plastic containers in a dark place. Total concentrations of $\mathrm{Cu}$ were determined by direct analysis of solutions resulted from dissolving samples in water and digesting with oxidizing reagents. In first case, $2.5-\mathrm{g}$ samples were placed in 100-ml beakers and dissolved in about $10 \mathrm{ml}$ of water and then diluted to $50 \mathrm{ml}$. 
Wet acid digestion was carried out in open vessels as following: 2.5-g samples were placed in 250-ml beakers and dissolved with $10 \mathrm{ml}$ of a $1+1 \mathrm{HNO}_{3}$ solution. Resulting aliquots were brought to boil on a hot plate and refluxed for $2 \mathrm{~h}$ under cover glasses. After cooling, $10 \mathrm{ml}$ of a $30 \%(m / v) \quad \mathrm{H}_{2} \mathrm{O}_{2}$ solution were added and sample solutions were heated to reduce volume to about $1 \mathrm{ml}$. Residues left were dissolved with water and made up to $50 \mathrm{ml}$. In both cases, resulting 5.0\% $(\mathrm{m} / \mathrm{v})$ honey solutions were directly aspirated to F-AAS and analyzed versus external aqueous standard solutions. Three independent analyses were made for each honey, and respective blanks were considered in final results.

\section{Resin Conditioning and Chemical Fractionation}

Amberlite XAD-16 was initially dried at $110^{\circ} \mathrm{C}$ in an oven for $4 \mathrm{~h}$ and then, its $1.0 \mathrm{-g}$ portions were wetted with methanol, subsequently with water, and finally, poured into columns. Resin beds formed were washed with $10 \mathrm{ml}$ of a 1-mol $1^{-1} \mathrm{HCl}$ solution and next with $20 \mathrm{ml}$ of water to remove excessive $\mathrm{HCl}$. Portions $(1.0 \mathrm{~g})$ of Dowex $50 \mathrm{~W} \times$ 8-200 as received were wetted with water and then poured into columns. Resin beds formed were washed with $10 \mathrm{ml}$ of a 1 -mol $\mathrm{l}^{-1} \mathrm{HCl}$ solution and then with $20 \mathrm{ml}$ of water. It was followed by rinsing them with $10 \mathrm{ml}$ of a $1 \mathrm{~mol}^{-1}$ $\mathrm{NaOH}$ solution and finally, with $20 \mathrm{ml}$ of water to remove excessive $\mathrm{NaOH}$. Conditioning solutions and water were

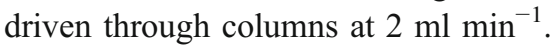

A two-column SPE procedure was used to partition $\mathrm{Cu}$ species in honeys due to their chemical properties (chemical fractionation). Accordingly, 50-ml 5.0\% $(\mathrm{m} / \mathrm{v})$ honey

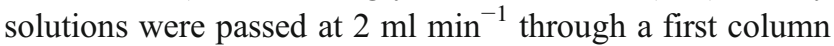
with Amberlite XAD-16 to retain hydrophobic $\mathrm{Cu}$ species. Effluents of this column were directly passed through a second column at $2 \mathrm{ml} \mathrm{min}{ }^{-1}$ to retain cationic $\mathrm{Cu}$ species on Dowex $50 \mathrm{~W} \times 8-200$. After passing $40 \mathrm{ml}$ of sample solutions, 10-ml effluents from the first and the second columns were sampled to evaluate contents of $\mathrm{Cu}$ in polyphenolic and residual $\mathrm{Cu}$ species fractions, respectively. Columns were split up and cationic $\mathrm{Cu}$ species retained by the second column were eluted using $10 \mathrm{ml}$ of a $2-\mathrm{mol}^{-1} \mathrm{HCl}$ solution at $1 \mathrm{ml} \mathrm{min}^{-1}$.

\section{Physical Fractionation}

A Millipore (Billerica, MA, USA) 8200 UF stirred cell with a stirring bar and a 200-ml sample reservoir were used. Pressure in the call was maintained with compressed $\mathrm{N}_{2}$ and controlled by a pressure adjustment valve fitted with a pressure gauge. At first, $200 \mathrm{ml}$ of $5.0 \%(\mathrm{~m} / \mathrm{v})$ honey solutions were filtrated through Nylone $660.45 \mu \mathrm{m}$ membrane filters (Sigma-Aldrich).
Filtrates were collected and successively passed through Millipore Biomax PB polyethersulfone ultrafiltration membranes with MWCOs of 100, 50, 30, 10, and $5 \mathrm{kDa}$. Each time, permeates that left the cell after filtration through a membrane of a certain MWCO were collected and passed through the membrane with a lower MWCO. Portions $(10 \mathrm{ml})$ of respective permeates were taken to determine concentrations of $\mathrm{Cu}$ associated with species below the certain MWCO.

\section{Results and Discussion}

\section{Determination of $\mathrm{Cu}$ in Honey-Like Matrices}

Honey can be treated as an organic sample matrix containing mostly two simple carbohydrates, i.e., glucose and fructose, which contribute to it up to $0.80-0.85 \mathrm{~kg} \mathrm{~kg}^{-1}$ (Belitz et al. 2004). It can also include relatively high amounts of $\mathrm{K}$ and $\mathrm{Na}$ that both are recognized to be the most abundant mineral constituents of honey (Pohl 2009). Thus, direct F-AAS analysis of honey solutions resulted from dissolving its samples in water on the content of trace metals, like $\mathrm{Cu}$ for example would possibly be prone to matrix effects. To establish if these interferences are related to the presence of mentioned organic and/or mineral constituents, a honey-like matrix was prepared and contained on average $0.45 \mathrm{~kg} \mathrm{~kg}^{-1}$ of glucose, $0.40 \mathrm{~kg} \mathrm{~kg}^{-1}$ of fructose, $600 \mathrm{mg} \mathrm{kg}^{-1}$ of $\mathrm{K}$, and $150 \mathrm{mg} \mathrm{kg}^{-1}$ of $\mathrm{Na}$. Then, a set of $100-\mathrm{ml}$ solutions containing $1.0 \%, 2.5 \%, 5.0 \%, 7.5 \%, 10.0 \%, 15.0 \%$, and $20.0 \%(\mathrm{~m} / \mathrm{v})$ of this matrix in addition to $\mathrm{Cu}$ at a concentration of $0.20 \mathrm{mg}^{-1}$ were analyzed by F-AAS versus external aqueous standard solutions. Additionally, to check the effect of a real honey matrix on the performance of F-AAS for the determination of $\mathrm{Cu}$, water solutions of honeydew honey (HD1) were also prepared and analyzed on the content of $\mathrm{Cu}$ using external aqueous standard solutions.

Results of these analyses are given in Table 1. It can be seen that recovery of $\mathrm{Cu}$ gradually decreases when the content of the honey-like matrix is increasing. It reaches only $70 \%$ of the initial concentration in case of analysis of a $20.0 \%(\mathrm{~m} / \mathrm{v})$ honey-like matrix solution. However, measuring corresponding solutions but without both carbohydrates, it was established that concentrations of $\mathrm{Cu}$ determined using external calibration with aqueous standard solutions were on average $0.198 \pm 0.006 \mathrm{mg} \mathrm{l}^{-1}$. With respect to this, it was possible to conclude that analytical performance of F-AAS is predominantly affected by glucose and fructose, which change viscosity of solutions, especially when present in elevated quantities (Ioannidou et al. 2005; Lopez-Garcia et al. 1999). Under 
Table 1 Concentrations $\mathrm{Cu}$ determined in solutions containing different contents of honey-like ( $\mathrm{Na}, \mathrm{K}$, glucose, and fructose) and honeydew honey matrices using F-AAS external calibration with simple aqueous standard solutions

\begin{tabular}{|c|c|c|c|}
\hline \multirow{2}{*}{$\begin{array}{l}\text { Content } \\
(\% ; m / v)\end{array}$} & \multirow{2}{*}{$\begin{array}{l}\text { Honey-like matrix } \\
\text { Concentration }^{\mathrm{a}} \\
\left(\mathrm{mg} \mathrm{l}^{-1}\right)\end{array}$} & \multicolumn{2}{|c|}{ Honeydew honey (HD1) matrix } \\
\hline & & $\begin{array}{l}\text { Concentration }^{\mathrm{a}} \\
\left(\mathrm{mg} \mathrm{kg}^{-1}\right)\end{array}$ & $t_{\text {calculated }}{ }^{\mathrm{b}}$ \\
\hline 1.0 & $0.200 \pm 0.003$ & $1.25 \pm 0.16$ & -1.52 \\
\hline 2.5 & $0.199 \pm 0.004$ & $1.40 \pm 0.06$ & 0.75 \\
\hline 5.0 & $0.201 \pm 0.002$ & $1.44 \pm 0.07$ & - \\
\hline 7.5 & $0.189 \pm 0.004$ & $1.22 \pm 0.05$ & -1.77 \\
\hline 10.0 & $0.165 \pm 0.004$ & $1.07 \pm 0.08$ & -3.98 \\
\hline 15.0 & $0.154 \pm 0.002$ & NA & - \\
\hline 20.0 & $0.139 \pm 0.002$ & NA & - \\
\hline
\end{tabular}

$N A$ not analyzed

${ }^{a}$ Average values $(n=3) \pm$ SDs

${ }^{\mathrm{b}} t$ statistic for 4 degrees of freedom and at $95 \%$ level of confidence $\left(t_{\text {critical }}=2.78\right)$ was used to compare mean concentrations determined in a $5.0 \%(\mathrm{~m} / \mathrm{v})$ honeydew honey solution with those found in remaining honeydew honey solutions

such conditions, external calibration with aqueous standard solutions is not any more possible. Corresponding results were obtained when analyzing solutions with different proportions of honeydew honey (HD1), i.e., $1.0 \%, 2.5 \%, 5.0 \%, 7.5 \%$, and $10.0 \%(\mathrm{~m} / \mathrm{v})$. On the basis of $t$ test carried out (Table 1), it was found that differences between $\mathrm{Cu}$ concentrations obtained for $1.0 \%, 2.5 \%$, and $5.0 \%(\mathrm{~m} / \mathrm{v})$ honeydew honey solutions were statistically insignificant. Nevertheless, uncertainty of results achieved for the lowest concentrated honey solution was quite high $(13 \%$ as $\mathrm{RSD}, n=3)$. Analysis of much concentrated honeydew honey solutions, i.e., $7.5 \%$ and $10.0 \%(\mathrm{~m} / \mathrm{v})$, versus external calibration with aqueous standard solution gave notably lower $\mathrm{Cu}$ recoveries as compared to $2.5 \%$ and $5.0 \%(\mathrm{~m} / \mathrm{v})$ honey solutions.

\section{Direct Analysis of Honeys}

Concentrations of $\mathrm{Cu}$ and other transition metals in honey are commonly determined by F-AAS after sample digestion aimed at decomposing carbohydrate-rich matrix and releasing mineral constituents. For measurements of very low concentrations of this metal in honey $\left(<0.1 \mathrm{mg} \mathrm{kg}^{-1}\right)$, a more sensitive technique is required, and this is the case of atomic absorption spectrometry with electrothermal atomization (Vinas et al. 1997). Typically dry ashing or wet ash digestions are used for that purpose (Baroni et al. 2009; Nanda et al. 2009; Dag et al. 2006). Curiously, direct analysis of honey, including only simple dissolving of samples in water, is quite occasional (Soares dos Santos et al. 2008; Hernandez et al. 2005; LopezGarcia et al. 1999) even though such kind of analysis offers a reduced sample preparation time and a lower risk of losing measured elements or contaminating samples with impurities.

Sample handling and preparation of direct analysis of honey is undoubtedly easier, and hence, after verifying the effect of the honey matrix on the response of $\mathrm{Cu}$ in F-AAS, it was decided to analyze $5.0 \%(\mathrm{~m} / \mathrm{v})$ solutions of studied dark honeys against external calibration with aqueous standard solutions. Results obtained using this sample treatment were compared with those achieved after analysis of solutions originated from decomposition of samples with concentrated $\mathrm{HNO}_{3}$ and $30 \%(m / v) \quad \mathrm{H}_{2} \mathrm{O}_{2}$ using $t$ test (Table 2). It was found that differences between these two sets of $\mathrm{Cu}$ concentrations were statistically insignificant at a confidential level of $95.0 \%$. Precision of direct analysis results, evaluated from three independent replicates, was acceptable since it changed from $4.2 \%$ to $8.8 \%$ (with respect to RSDs). Accuracy was checked by examining recoveries of spiked samples of honeydew honey (HD1). Spiked and original sample solutions were measured under external calibration with aqueous standard solutions and apparent recoveries were determined. Their values achieved, i.e., $97.3 \pm 2.9 \%, 98.6 \pm 3.2 \%$, and $99.1 \pm 2.1 \%$ for spiking samples with $0.020,0.050$, and $0.070 \mathrm{mg} \mathrm{l}^{-1}$,
Table 2 Total concentrations of $\mathrm{Cu}$ obtained using direct analysis of honey (A) and after its mineralization in open vessel system (B) in addition to contributions of $\mathrm{Cu}$ species fractions distinguished using SPE

\footnotetext{
${ }^{a}$ Average values $(n=3) \pm$ SDs

${ }^{\mathrm{b}}$ Average values $(n=3) \pm$ pooled RSDs
}

\begin{tabular}{|c|c|c|c|c|c|c|}
\hline \multirow[t]{2}{*}{ Honey } & \multicolumn{2}{|c|}{ Concentration $^{\mathrm{a}}\left(\mathrm{mg} \mathrm{kg}^{-1}\right)$} & \multicolumn{4}{|c|}{ Fraction contribution ${ }^{\mathrm{b}}(\%)$} \\
\hline & A & $\mathrm{B}$ & Hydrophobic & Cationic & Residual & Sum \\
\hline B & $1.25 \pm 0.11$ & $1.44 \pm 0.13$ & $7.2 \pm 1.0$ & $39.2 \pm 3.8$ & $54.4 \pm 5.8$ & $100.8 \pm 7.0$ \\
\hline BG & $1.06 \pm 0.05$ & $1.10 \pm 0.06$ & $11.3 \pm 1.1$ & $55.7 \pm 2.8$ & $35.8 \pm 1.9$ & $102.8 \pm 3.6$ \\
\hline H1 & $1.08 \pm 0.05$ & $1.01 \pm 0.05$ & $15.7 \pm 1.2$ & $40.7 \pm 3.4$ & $42.6 \pm 2.7$ & $99.0 \pm 4.5$ \\
\hline $\mathrm{H} 2$ & $0.95 \pm 0.04$ & $1.02 \pm 0.07$ & $20.0 \pm 2.3$ & $33.7 \pm 2.5$ & $47.4 \pm 2.9$ & $101.1 \pm 4.5$ \\
\hline HD1 & $1.44 \pm 0.12$ & $1.54 \pm 0.06$ & $30.6 \pm 2.9$ & $46.5 \pm 3.9$ & $20.1 \pm 1.8$ & $97.2 \pm 5.2$ \\
\hline HD2 & $1.68 \pm 0.09$ & $1.70 \pm 0.10$ & $28.9 \pm 2.1$ & $42.6 \pm 2.8$ & $28.3 \pm 2.4$ & $99.8 \pm 4.2$ \\
\hline
\end{tabular}


respectively, supported that results of direct analysis are reliable and accurate.

Fractionation Pattern for $\mathrm{Cu}$ Obtained with Solid Phase Extraction and Ultrafiltration Approaches

It is generally accepted that food products are suitable for consumption if they do not contain minor and trace element contaminants above certain permitted limits. Unfortunately, such limits are commonly expressed as total concentrations, but it is well recognized that bioavailability and metabolic activity of elements are related to physicochemical forms they are present (Dean 2007). Amber to dark color honeys are presumed to contain much higher amounts of flavonoids and phenolic acids as compared to light color honeys (Pohl and Sergiel 2010; Bogdanov et al. 2008); hence, partitioning of $\mathrm{Cu}$ due to hydrophobicity, charged and molecular weight of its species in these honeys is worth of studying in view of their food safety and quality. Accordingly, solutions of analyzed honeys were treated with a two-column SPE fractionation scheme. In addition, solutions of three selected honeys (BG, H1, and HD1) were subjected to UF using membrane filters with MWCO within 5-100 kDa in order to compare results obtained for both fractionation approaches.

In reference to results of chemical fractionation (Table 2), it can be seen that predominant fractions for $\mathrm{Cu}$ are almost equally abundant cationic and residual species. These $\mathrm{Cu}$ species classes account for $34-56 \%$ and $20-54 \%$, respectively, regarding total concentrations of $\mathrm{Cu}$ in analyzed amber to dark honeys. It seems that these two $\mathrm{Cu}$ fractions particularly include species with molecular weight $<5 \mathrm{kDa}$ since in case of BG, H1, and HD1 honeys sums of contributions of cationic and residual fractions well corresponds to respective contributions of this low molecular weight fraction (LMW: from $67 \%$ to $88 \%$ ) obtained by UF (Table 3). The first group of species (cationic fraction) could be simple ions of $\mathrm{Cu}$ and its labile complexes. In view of biological activity of small charged element species ingested with food in living organisms, it is valid to speculate that this fraction is the most bioavailable (Turnlund et al. 1997) and should be considered when assessing, for example, toxic levels of $\mathrm{Cu}$ in case of its elevated concentrations in honeys. Mentioned residual species could be stable and/or neutral complexes with relatively LMW compounds, i.e., some hydroxycaroboxylic acids (citric, oxalic, ascorbic, gluconic, lactic) and amino acids (particularly histidine, methionine, and cysteine). These species also make ingested $\mathrm{Cu}$ readily absorbable (Turnlund et al. 1997).

The contribution of hydrophobic $\mathrm{Cu}$ species was found to be within $7-31 \%$ when regarding total concentrations of this element. Apparently, this fraction is likely to be attributed to species of $\mathrm{Cu}$ bound to apolar and moderately polar high molecular weight (HMW) organic compounds of
Table 3 Contribution of $\mathrm{Cu}$ species fractions distinguished using UF

\begin{tabular}{llll}
\hline Fraction & \multicolumn{3}{l}{ Contribution $^{\mathrm{a}}(\%)$} \\
\cline { 2 - 4 } & BG & HD1 & H1 \\
\hline$>0.45 \mu \mathrm{m}$ & $-^{\mathrm{b}}$ & $-^{\mathrm{b}}$ & $-^{\mathrm{b}}$ \\
$>100 \mathrm{kDa}$ & $-^{\mathrm{b}}$ & $-^{\mathrm{b}}$ & $-^{\mathrm{b}}$ \\
$50-100 \mathrm{kDa}$ & $1.3 \pm 0.1$ & $2.7 \pm 0.9$ & $4.5 \pm 0.3$ \\
$30-50 \mathrm{kDa}$ & $--^{\mathrm{b}}$ & $--^{\mathrm{b}}$ & $--^{\mathrm{b}}$ \\
$10-30 \mathrm{kDa}$ & $10.2 \pm 1.9$ & $26.8 \pm 4.2$ & $18.3 \pm 1.2$ \\
$5-10 \mathrm{kDa}$ & $-{ }^{\mathrm{b}}$ & $-{ }^{\mathrm{b}}$ & $-{ }^{\mathrm{b}}$ \\
$<5 \mathrm{kDa}$ & $88.1 \pm 4.1$ & $67.1 \pm 3.5$ & $80.1 \pm 3.9$ \\
Sum & $99.9 \pm 4.5$ & $96.6 \pm 5.5$ & $102.9 \pm 4.1$ \\
\hline
\end{tabular}

${ }^{\text {a }}$ Averaged values $(n=3) \pm \mathrm{SDs}$

${ }^{\mathrm{b}}$ Concentrations of $\mathrm{Cu}$ in a filtrate is the same or a little higher than in a feeding solution

$50-100 \mathrm{kDa}$ and $>100 \mathrm{kDa}$. A notable correlation between sums of contributions of these two HMW fractions and shares of respective hydrophobic fractions distinguished in BG, H1, and HD1 honeys was observed. Considering that complexes of polyphenols with $\mathrm{Cu}$ impair its bioavailability from food (Vitali et al. 2008), this fraction can be regarded as highly inaccessible and possibly have a decreasing effect on dietary $\mathrm{Cu}$ intake. Information on this class of species is also important in respect to a role that polyphenols play in inhibiting $\mathrm{Cu}$-induced oxidation process and free radical damage by forming stable complexes with $\mathrm{Cu}$ ions (Andrade et al. 2005; Hadi et al. 2007).

With reference to accuracy and precision, the SPE fractionation procedure enables recover of $\mathrm{Cu}$ from analyzed honeys with relative errors within $-2.8 \%$ to $+2.8 \%$. Precision expressed as RSD and estimated for separated fractions was found to range from $1.0 \%$ to $5.8 \%$. Corresponding accuracy for the UF procedure was within $-3.4 \%$ to $+2.9 \%$. Precision of repeated measurements $(n=3)$ varied between $0.1 \%$ and $4.1 \%$. All these figures verify dependability of both fractionation procedures used for $\mathrm{Cu}$ partitioning.

\section{Conclusions}

A very simple method of total content analysis honey by means of F-AAS was demonstrated on the example of $\mathrm{Cu}$. It can save time and costs of honey pre-treatment before analysis by F-AAS using direct aspiration of honey solutions and external calibration with aqueous standard solutions.

It seems that this concomitant element is highly bioaccessible from amber to dark honeys since percentage shares of cationic and residual $\mathrm{Cu}$ species fractions were 
found to change within $67-94 \%$ in relation to total concentrations. Both $\mathrm{Cu}$ species classes can be presumed to be simply available, and thus, their evaluation is very important in reference to quality, safety, and nutrition values of honey. In this regard, proposed simple and versatile SPE and UF methods to classify and determine relevant groups of $\mathrm{Cu}$ species associated with compounds of different MWs appear to be relevant for evaluating bioavailability of $\mathrm{Cu}$. Data obtained with both approaches are equally important and comprehensive as they give the rightest answer about chemical nature of possible group of species of $\mathrm{Cu}$ and their availability from honey. These two complementary procedures can also be applied to partition other biologically relevant elements in honey.

Open Access This article is distributed under the terms of the Creative Commons Attribution Noncommercial License which permits any noncommercial use, distribution, and reproduction in any medium, provided the original author(s) and source are credited.

\section{References}

Andrade RG, Dalvi LT, Silva JMC, Lopes GKB, Alonso A, HermesLima M (2005) The antioxidant effect of tannic acid on the in vitro copper-mediated formation of free radicals. Arch Biochem Biophys 437:1-9

Baroni MV, Arrua C, Nores ML, Faye P, del Pilar DM, Chiabrando GA, Wunderlin DA (2009) Composition of honey from Cordoba (Argentina): assessment of North/South provenance by chemometrics. Food Chem 114:727-733

Belitz HD, Grosch W, Schieberle P (2004) Food chemistry. Springer Verlag GmbH, Heilderberg (Germany)

Bogdanov S, Jurendic T, Sieber R, Gallmann P (2008) Honey for nutrition and health: a review. Am J Col Nutr 27:677-689

Bremner I (1998) Manifestations of copper excess. Am J Clin Nutr 67:1069S-1073S

Dag A, Afik O, Yeselson Y, Schaffer A, Shafir S (2006) Physical, chemical and palynological characterization of avocado (Persea americana Mill.) honey in Israel. Int J Food Sci Technol 41:387-394

Dean JR (2007) Bioavailability, bioaccessibility and mobility of environmental contaminants. John Wiley \& Sons Ltd., Chichester (West Sussex, England)
Gaetke LM, Chow CK (2003) Copper toxicity, oxidative stress, and antioxidant nutrients. Toxicology 189:147-163

Hadi SM, Bhat SH, Azmi AS, Hanif S, Shamim U, Ullah MF (2007) Oxidative breakage of cellular DNA by plant polyphenols. a putative mechanism for anticancer properties. Semin Cancer Biol 17:370-376

Hernandez OM, Fraga JMG, Jimenez AI, Jimenez F, Arias JJ (2005) Characterization of honey from the Canary Islands: determination of the mineral content by atomic absorption spectrometry. Food Chem 93:449-458

Ioannidou MD, Zachariadis GA, Anthemidis AN, Stratis JA (2005) Direct determination of toxic trace metals in honey and sugars using inductively coupled plasma atomic emission spectrometry. Talanta 65:92-97

Lopez-Garcia I, Vinas P, Blanco C, Hernandez Cordoba M (1999) Fast determination of calcium, magnesium and zinc in honey using continuous flow flame atomic absorption spectrometry. Talanta 49:597-602

Nanda V, Singh B, Kukreja VK, Bawa AS (2009) Characterisation of honey produced from different fruit plants of northern India. Int J Food Sci Technol 44:2629-2636

Paramas AMG, Barez JAG, Garcia-Villanova RJ, Pala TR, Albajar RA, Sanchez JS (2000) Geographical discrimination of honeys by using mineral composition and common chemical quality parameters. J Sci Food Agric 80:157-165

Pohl P (2009) Determination of metal content in honey by atomic absorption and emission spectrometries. Trends Anal Chem 28:117-128

Pohl P, Sergiel I (2010) Direct determination of the total concentrations of copper, iron and manganese and their fractionation forms in freshly ripened honeys by means of flame atomic absorption spectrometry. Microchim Acta 168:915

Soares dos Santos J, Soares dos Santos N, Pires dos Santos ML, Novaes dos Santos S, de Jesus Lacerda JJ (2008) Honey classification from semi-arid, Atlantic and transitional forest zones in Bahia, Brazil. J Braz Chem Soc 19:502-508

Turnlund JR, Scott KC, Peiffer GL, Jang A, Keyes WR, Keen C, Sakanashi T (1997) Copper status of young men consuming a low-copper diet. Am J Clin Nutr 65:72-78

Vinas P, Lopez-Garcia I, Lanzon M, Hernandez-Cordoba M (1997) Direct determination of lead, cadmium, zinc, and copper in honey by electrothermal atomic absorption spectrometry using hydrogen peroxide as a matrix modifier. J Agr Food Chem 45:39523956

Vitali D, Dragojevic IV, Sebecic B (2008) Bioaccessibility of Ca, Mg, $\mathrm{Mn}$ and $\mathrm{Cu}$ from whole grain tea-biscuits. impact of proteins, phytic acid and polyphenols. Food Chem 110:62-68

Wapnir RA (1998) Copper absorption and bioavailability. Am J Clin Nutr 67(suppl):1054S-1060S 